\title{
Pemberian Rizobakteri dan Coumarin pada Pertumbuhan dan Pembentukan Umbi Tanaman Kentang (Solanum tuberosum L.)
}

\author{
Rhizobacteria and Coumarin Applications on Growth and \\ Tuber Formation of Potato (Solanum tuberosum L.)
}

\author{
Henny Puspita Sari ${ }^{1 *}$, WarnitaWarnita ${ }^{2}$, dan Indra Dwipa ${ }^{3}$ \\ ${ }^{1}$ Program Studi S2 Agronomi, Fakultas Pertanian, Universitas Andalas \\ ${ }^{2}$ Program Studi Agroteknologi, Fakultas Pertanian, Universitas Andalas \\ Kampus Unand Limau Manis Kec. Pauh, Kota Padang 25163, Sumatera Barat, Indonesia
}

Diterima 24 Mei 2018/Disetujui 20 Mei 2019

\begin{abstract}
Increasing the productivity of potato crops will require the availability of tubers that are of high quality and resistant to disease. Giving isolates rhizobacteria and coumarin is expected to increase the growth and formation of potato tubers. The purpose of this study was to obtain the best types of rhizobacteria and coumarin concentrations in increasing the productivity of potato plants. The research was conducted in the experimental garden of the Center for Technology Transfer and Agricultural Zone Development of Andalas University, Alahan Panjang, Solok Regency, West Sumatra, from October 2016 to January 2017. The study used a 2-factor complete randomized design with three replications. The first factor was rhizobacterial isolates, namely without bacteria, BT.4.1 isolates, BT.4.2 isolates, BT.4.3 isolates. The second factor was the concentration of coumarin growth inhibitors, namely $0,50,100$, and $150 \mathrm{mg} \mathrm{L^{-1 }}$. The characters observed were morphological characterization rhizobacteria, leaf area, relative growth rate, growth rate potato tubers at 1-month-old, fresh weight of tubers aged 100 days after planting, tuber classes, namely: large, medium and small. Observation data were analyzed by the F test, followed by the HSD test at 5\% level. The results showed that BT.4.1 and BT.4.2 rhizobacteria with coumarin 100 $m g L^{-1}$ and $150 \mathrm{mg} \mathrm{L}^{-1}$ increased the growth of potato plants, while the results of potato plants were more affected by the application of BT.4.1 and BT rhizobacteria.
\end{abstract}

Keywords: Granola, leaf area, growth rate potato tuber, tuber, relative growth rate

\section{ABSTRAK}

Peningkatan produktivitas tanaman kentang, akan membutuhkan ketersedian umbi yang berkualitas dan tahan terhadap penyakit. Pemberian isolat rizobakteria dan coumarin diharapkan dapat meningkatkan pertumbuhan dan pembentukan umbi tanaman kentang. Tujuan penelitian ini untuk mendapatkan jenis rizobakteria dan konsentrasi coumarin yang terbaik dalam peningkatan produktivitas tanaman kentang. Penelitian dilaksanakan di kebun percobaan Pusat Alih Teknologi dan Pengembangan Kawasan Pertanian Universitas Andalas, Alahan Panjang, Kabupaten Solok, Sumatera Barat, pada bulan Oktober 2016 sampai dengan Januari 2017. Penelitian menggunakan rancangan acak lengkap 2 faktor dengan 3 ulangan. Faktor pertama adalah isolat rizobakteri yaitu tanpa bakteri, isolat BT.4.1, isolat BT.4.2, isolat BT.4.3. Faktor kedua adalah konsentrasi zat penghambat tumbuh coumarin yaitu 0, 50, 100, dan $150 \mathrm{mg} \mathrm{L} \mathrm{L}^{-1}$. Karakter yang di amati adalah karakterisasi morfologi rhizobakteri, luas daun, laju pertumbuhan relatif, laju tumbuh umbi tanaman kentang pada umur satu bulan, bobot segar umbi per tanaman umur 100 HST, kelas umbi yaitu: large, medium dan small. Data hasil pengamatan dianalisis dengan uji F, dilanjutkan dengan uji BNJ pada taraf 5\%. Hasil penelitian menunjukkan bahwa rizobakteri BT.4.1 dan BT.4.2 dengan coumarin $100 \mathrm{mg} \mathrm{L}^{-1}$ dan $150 \mathrm{mg} \mathrm{L^{-1 }}$ dapat meningkatkan pertumbuhan tanaman kentang, sedangan untuk hasil tanaman kentang lebih dipengruhi pada pemberian rizobakteri BT.4.1 dan BT.4.3.

Kata kunci: Granola, luas daun, laju tumbuh umbi, umbi, laju pertumbuhan relatif

\footnotetext{
* Penulis untuk korespondensi. e-mail: hpssp.henny@gmail.com
} 


\section{PENDAHULUAN}

Kentang merupakan sumber karbohidrat yang memiliki potensi sebagai penunjang program diversifikasi pangan di Indonesia, hal ini dapat dilihat dari tingginya konsumsi kentang pada tahun 2015 sebesar 2,294 kg per kapita per tahun (PUSTADIN, 2015). FAO, (2014) melaporkan bahwa konsumsi kentang menempati urutan ke lima di dunia setelah padi, gandum, kedelai dan jagung, sedangkan di benua Asia konsumsi kentang menempati urutan ke tiga setelah padi dan gandum

Produktivitas kentang di Indonesia secara nasional masih rendah, yaitu: pada tahun 2016 berkisar 18.23 ton ha-1, khususnya Sumatera Barat berkisar 19.49 ton ha' ${ }^{-1}$ (Badan Pusat Statistik, 2017), sedangkan produktivitas kentang di negara lain yaitu: Australia 39.69 ton ha ${ }^{-1}$, Amerika 47.15 ton $\mathrm{ha}^{-1}$, Jepang 30.65 ton $\mathrm{ha}^{-1}$ dan Laos 30.04 ton ha-1 (FAO, 2015).

Kendala utama dalam peningkatan produktivitas tanaman kentang adalah ketersediaan bibit yang berkualitas secara kontinu serta bebas dari organisme pengganggu tanaman. Tanaman kentang yang dibudidayakan umumnya memiliki ketahanan yang rendah terhadap berbagai penyakit terutama penyakit layu bakteri. Solusi terbaik untuk mereduksi penyakit pada tanaman kentang adalah menginduksi dengan rizhobakteri sehingga tanaman menjadi tahan terhadap penyakit.

Rizobakteri hidup pada daerah rizosfer atau daerah perakaran, berperan sebagai pemacu pertumbuhan tanaman dan sebagai agens biokontrol terhadap penyakit, sehingga mampu meningkatkan hasil tanaman (Elango et al., 2013; Rodrigo et al., 2013). Selain penggunaan rizobakteri untuk meningkatkan pertumbuhan dan perlindungan tanaman dari patogen, serta pembentukan umbi pada tanaman kentang dapat diperoleh dari aplikasi pengatur tumbuh dengan pemberian coumarin. Efek bakteri yang diberikan juga memicu keterlibatan coumarin dalam merespon pertumbuhan tanaman, pembentukan kembali mikroba dalam tanah dan melindungi tanaman dari jamur patogen (Derek et al., 2018; Li et al., 2011). Coumarin merupakan produk alami tanaman yang berasal dari jalur fenilpropanoid ditemukan menumpuk di jaringan akar, yang memiliki peran penting dalam biokimia dan fisiologi tanaman (Kai et al., 2006), sebagai antioksidan dan inhibitor enzim (Chattha et al., 2016). Tujuan penelitian ini untuk mendapatkan jenis rizobakteria dan konsentrasi coumarin yang terbaik dalam peningkatan produktivitas tanaman kentang.

\section{BAHAN DAN METODE}

Penelitian dilaksanakan di kebun percobaan Pusat Alih Teknologi dan Pengembangan Kawasan Pertanian Universitas Andalas, Alahan Panjang, Kabupaten Solok, Sumatera Barat, pada ketinggian tempat 1,616 m dpl. Kisaran curah hujan selama penelitian rata-rata $505 \mathrm{~mm}$ dengan rata-rata 15 hari hujan.

Percobaan menggunakan rancangan acak lengkap (RAL) dengan 2 faktor dan 3 ulangan. Faktor pertama adalah 4 isolat bakteri (Tanpa bakteri isolat, BT.4.1, BT.4.2,
BT.4.3) dan faktor kedua adalah 4 konsentrasi coumarin ( 0 , $50,100,150 \mathrm{mg} \mathrm{L}^{-1}$ ). Setiap kombinasi dilakukan dengan 3 kali ulangan, sehingga didapatkan 48 unit percobaan dan masing-masing unit terdiri dari 10 tanaman dengan total 480 populasi tanaman.

Media tanam yang digunakan adalah campuran tanah dan pupuk kandang (20 ton $\mathrm{ha}^{-1}$ ) dengan perbandingan 2 : 1 (disterilkan terlebih dahulu) dan dimasukkan kedalam polibag ukuran $5 \mathrm{~kg}$. Suspensi isolat rizobakteri (Tabel 1) dengan kepadatan inokulum $10^{8}$ di aplikasikan sebanyak dua kali yaitu saat sebelum penanaman, dan pada umur 28 HST (Hari Setelah Tanam) sebanyak $10 \mathrm{~mL}$ dengan cara disiram di tanah sekitar perakaran tanaman kentang. Perlakuan konsentrasi coumarin dilakukan dengan cara disemprotkan pada seluruh bagian tajuk tanaman ( $50 \mathrm{~mL}$ per tanaman) pada umur 28, 35, 42 HST. Benih kentang yang digunakan adalah varietas granola $\left(\mathrm{G}_{0}\right)$ yang berasal dari Dieng Banjarnegara, Jawa Tengah. Benih $\mathrm{G}_{0}$ yang digunakan untuk merbanyak benih tanaman kentang yang bermutu.

Pengamatan karakterisasi morfologi rhizobakteri meliputi: bentuk koloni, elevasi koloni, tepi koloni, ukuran, warna, uji gram untuk mengetahui apakah bakteri bersifat gram positif (Resistensi terhadap alkali $(1 \% \mathrm{KOH})$ larut) atau negatif (Resistensi terhadap alkali $(1 \% \mathrm{KOH})$ lebih pekat) dan uji hipersensitif dengan cara menyuntikan suspensi rizobakteri indigenus secara interseluler pada jaringan permukaan bawah daun tanaman Mirabillis Jalapa dan mengamati perkembangan gejala selama 2 x 24 jam (Yanti, et al., 2013).

Pengamatan pertumbuhan tanaman meliputi luas daun yang diukur menggunakan Leaf Area Meter ${ }^{\circledR}$ Weiber Model No ACM - 52301j, laju pertumbuhan relatif (RGR) menggunakan rumus yang dikemukakan oleh Gardner et al., (1991): (RGR) $=\ln \mathrm{W}_{2}-\ln \mathrm{W}_{1} / \mathrm{t}_{2}-\mathrm{t}_{1}$ (g per tanaman per hari), laju tumbuh umbi (LTU) menggunakan rumus yang dikemukakan oleh Syarif (2004): $\mathrm{LTU}=\mathrm{W}_{2}$ umbi $-\mathrm{W}_{1}$ umbi $/ \mathrm{t}_{2}-\mathrm{t}_{1} \times 1 / \mathrm{S}$ (g per tanaman per hari). $\ln \mathrm{W}_{1} \ln \mathrm{W}_{2}$ merupakan logaritma natural dari bobot kering total tanaman pada waktu $t_{1}$ dan $t_{2}, W_{1}$ dan $W_{2}$ umbi merupakan bobot kering umbi pada waktu $t_{1}$ dan $t_{2}, t_{1}$ merupakan waktu pengamatan tertentu, dan $\mathrm{t}_{2}$ merupakan waktu pengamatan sesudah $\mathrm{t}_{1}$, $\mathrm{S}$ merupakan sampel. Pengukuran dilakukan pada sampel destruktif pada umur 35, 42, 49, 56, dan 63 HST, diambil sebanyak 1 sampel per 7 hari.

Pengamatan hasil meliputi bobot segar umbi per tanaman (g) yang diamati saat panen (umur $100 \mathrm{HST}$ ). Kelas umbi yaitu: Large (L)/besar : > 20 g, Medium (M)/sedang 5-20 g dan Small (S)/kecil $<5$ g (Direktorat Perbenihan Hortikultura, 2014). Data hasil pengamatan dianalisis dengan uji $\mathrm{F}$, dilanjutkan dengan uji BNJ pada taraf 5\%.

\section{HASIL DAN PEMBAHASAN}

\section{Karakter Rizobakteri}

Hasil analisis sifat morfologi dari 3 isolat rizobakteri yang di ambil dari perakaran tanaman kentang memiliki bentuk, warna, elevasi yang seragam, sedangkan ukuran koloni beragam. Rizobakteri bersifat gram negatif, sedangkan 
uji reaksi hipersensitif menunjukkan reaksi positif dengan menunjukan gejala kematian sel, kekeringan dan nekrosis pada area daun yang disuntikan dengan suspensi bakteri (Tabel 1).

\section{Pertumbuhan Tanaman}

Pemberian rizobakteri dan coumarin meningkatkan pertumbuhan tanaman kentang, dibandingkan dengan tanpa rizobakteri. Pertumbuhan vegetatif tanaman kentang nyata lebih baik (Tabel 2, 3, dan 4). Luas daun pada tanaman kentang meningkat setelah diintroduksi dengan isolat rizobakteri dan coumarin pada interaksi BT.4.1 dan coumarin $100 \mathrm{mg} \mathrm{L}^{-1}$ dan BT.4.2 dan coumarin $150 \mathrm{mg} \mathrm{L}^{-1}$ dibanding tanpa isolat rizobakteri dan coumarin $150 \mathrm{mg} \mathrm{L}^{-1}$.

Laju pertumbuhan relatif meningkat pada tanaman yang diintroduksi dengan isolat rizobakteri BT.4.2. dan coumarin $150 \mathrm{mg} \mathrm{L}^{-1}(0.14 \mathrm{~g}$ per tanaman per hari). Laju tumbuh umbi meningkat pada tanaman yang diintroduksi dengan isolat rizobakteri BT.4.2 dan coumarin $150 \mathrm{mg} \mathrm{L}^{-1}$. Dalam hal ini terlihat bahwa isolat rizobakteri dan coumarin mampu meningkatkan pertumbuhan tanaman.

Peningkatan luas daun, laju pertumbuhan relatif dan laju tumbuh umbi tanaman kentang pada umur 63 HST, diduga karena rizobakteri dapat meningkatkan ketersediaan unsur hara dalam tanah terutama $\mathrm{N}, \mathrm{P}$ dan memiliki kemampuan untuk menghasilkan hormon IAA dalam tanah. Ketersediaan nutrisi pada media tumbuh pada awal penanaman, berpengaruh terhadap eksudat yang dikeluarkan akar tanaman, sehingga dapat dimanfaatkan oleh rizobakteri untuk sumber nutrisi. Bakteri Bacillus sp. mengkolonisasi perakaran tanaman dan membantu penyerapan unsur hara, pengembangan akar dan pengambilan serta metabolisme nitrogen (Li et al., 2011; Fifi et al., 2018).

Beberapa hasil penelitian menjelaskan bahwa bakteri Bacillus (Zakry et al., 2012), dan Pseudomonas telah diidentifikasi sebagai PGPR ke tanaman jagung melalui fiksasi nitrogen biologis (BNF), pelarut fosfat dan produksi fitohormon. BNF oleh PGPR berkontribusi hingga 12-70\% dari total serapan N (Piromyou et al., 2011), memperbaiki $\mathrm{N}$ rata-rata $20 \mathrm{~kg} \mathrm{ha}^{-1}$ per tahun (Jnawali et al., 2015), dan mengandung fosfat masing - masing sekitar 1-50\% dan 0.1$0.5 \%$ dari total populasi yang di aplikasikan (Souza et al., 2015). Identifikasi 101 isolat milik genera Burkholderia, Cedecea, Cronobacter, Enterobacter, Pantoea dan Pseudomonas yang mampu melarutkan trikalsium fosfat $\left[\mathrm{Ca}_{3}\left(\mathrm{PO}_{4}\right)_{2}\right]$ (Souza et al., 2013), serta menghasilkan fitohormon IAA murni pada Bacillus sp. sebesar $141 \mathrm{ppm}$ (Fifi et al., 2018).

Ahemada dan Kibret (2014) menjelaskan, bahwa 80\% isolat rizobakteri memiliki kemampuan untuk mensintesis dan melepaskan auksin sebagai metabolit sekunder. Secara umum, IAA disekresi oleh pengaruh rizobakteri dengan berbagai proses perkembangan tanaman, karena hormon IAA endogen pada tanaman dapat dirubah oleh akuisisi IAA yang telah disekresikan oleh bakteri (Glick, 2012). Senyawa coumarin berinteraksi dengan jalur sinyal IAA pada tanaman petunia hybrida, dalam mempengaruhi metabolisme IAA, sehingga mempengaruhi konsentrasi IAA di dalam tanaman (Lupini et al., 2010; Cheynier et al., 2013).

Meningkatnya konsentrasi IAA di dalam tanaman menyebabkan penurunan pada konsentrasi GA, dan terjadinya perubahan struktur pada anatomis daun menjadi lebih tebal, sehingga aktivitas fotosintesis meningkat (Kefeli

Tabel 1. Karakterisasi bentuk morfologi dan fisiologi isolat rizobakteri dari perakaran tanaman kentang

\begin{tabular}{lrrrr}
\hline \multirow{2}{*}{ Isolat bakteri } & \multicolumn{4}{c}{ Konsentrasi Coumarin $\left(\mathrm{mg} \mathrm{L}^{-1}\right)$} \\
\cline { 2 - 5 } & 0 & 50 & 100 & 150 \\
\hline Tanpa & $386.83 \mathrm{Aa}$ & $1,466.67 \mathrm{Ab}$ & $424.00 \mathrm{Aa}$ & $1,196.83 \mathrm{ABab}$ \\
BT.4.1 & $488.89 \mathrm{Aa}$ & $527.33 \mathrm{Aa}$ & $2,896.67 \mathrm{Bb}$ & $759.86 \mathrm{Aa}$ \\
BT.4.2 & $532.00 \mathrm{Aa}$ & $915.57 \mathrm{Aa}$ & $593.78 \mathrm{Aa}$ & $1,927.00 \mathrm{Bb}$ \\
BT.4.3 & $1,182.86 \mathrm{Aa}$ & $858.67 \mathrm{Aa}$ & $1,230.14 \mathrm{Aa}$ & $601.33 \mathrm{Aa}$ \\
\hline
\end{tabular}

Tabel 2. Luas daun $\left(\mathrm{cm}^{2}\right)$ tanaman kentang umur 63 HST pada pemberian isolat Rizobakteri dan konsentrasi coumarin

\begin{tabular}{lcrrr}
\hline \multirow{2}{*}{ Isolat bakteri } & \multicolumn{4}{c}{ Konsentrasi Coumarin $\left(\mathrm{mg} \mathrm{L}^{-1}\right)$} \\
\cline { 2 - 5 } & 0 & 50 & 100 & 150 \\
\hline Tanpa & $386.83 \mathrm{Aa}$ & $1,466.67 \mathrm{Ab}$ & $424.00 \mathrm{Aa}$ & $1,196.83 \mathrm{ABab}$ \\
BT.4.1 & $488.89 \mathrm{Aa}$ & $527.33 \mathrm{Aa}$ & $2,896.67 \mathrm{Bb}$ & $759.86 \mathrm{Aa}$ \\
BT.4.2 & $532.00 \mathrm{Aa}$ & $915.57 \mathrm{Aa}$ & $593.78 \mathrm{Aa}$ & $1,927.00 \mathrm{Bb}$ \\
BT.4.3 & $1,182.86 \mathrm{Aa}$ & $858.67 \mathrm{Aa}$ & $1,230.14 \mathrm{Aa}$ & $601.33 \mathrm{Aa}$ \\
\hline
\end{tabular}

Keterangan: *Angka-angka pada arah horizontal yang diikuti huruf kecil yang sama dan angka-angka pada arah vertikal yang diikuti oleh huruf besar yang sama berbeda tidak nyata berdasarkan uji BNJ taraf 5\%.** Data yang disajikan adalah data asli, untuk sidik ragam dan BNJ adalah data transformasi $\sqrt{X+0.5}$ 
Tabel 3. Laju pertumbuhan relatif (g per tanaman per hari) tanaman kentang umur 56-63 HST pada pemberian isolat Rizobakteri dan konsentrasi coumarin

\begin{tabular}{lcccc}
\hline \multirow{2}{*}{ Isolat bakteri } & \multicolumn{4}{c}{ Konsentrasi Coumarin $\left(\mathrm{mg} \mathrm{L}^{-1}\right)$} \\
\cline { 2 - 5 } & 0 & 50 & 100 & 150 \\
\hline Tanpa & $0.05 \mathrm{aA}$ & $0.06 \mathrm{aA}$ & $0.03 \mathrm{aA}$ & $0.08 \mathrm{aAB}$ \\
BT.4.1 & $0.06 \mathrm{aA}$ & $0.09 \mathrm{aA}$ & $0.13 \mathrm{aA}$ & $0.09 \mathrm{aAB}$ \\
BT.4.2 & $0.06 \mathrm{abA}$ & $0.02 \mathrm{aA}$ & $0.05 \mathrm{abA}$ & $0.14 \mathrm{bB}$ \\
BT.4.3 & $0.05 \mathrm{aA}$ & $0.06 \mathrm{aA}$ & $0.08 \mathrm{aA}$ & $0.02 \mathrm{aA}$ \\
\hline
\end{tabular}

Keterangan: *Angka-angka pada arah horizontal yang diikuti huruf kecil yang sama dan angka-angka pada arah vertikal yang diikuti oleh huruf besar yang sama berbeda tidak nyata berdasarkan uji BNJ taraf $5 \%$.** Data yang disajikan adalah data asli, untuk sidik ragam dan $\mathrm{BNJ}$ adalah data transformasi $\sqrt{X+0.5}$

Tabel 4. Laju tumbuh umbi (g per tanaman per hari) tanaman kentang umur 56-63 HST pada pemberian isolat Rizobakteri dan konsentrasi coumarin

\begin{tabular}{lcccc}
\hline \multirow{2}{*}{ Isolat bakteri } & \multicolumn{4}{c}{ Konsentrasi coumarin $\left(\mathrm{mg} \mathrm{L}^{-1}\right)$} \\
\cline { 2 - 5 } & 0 & 50 & 100 & 150 \\
\hline Tanpa & $0.68 \mathrm{aA}$ & $1.83 \mathrm{aA}$ & $3.24 \mathrm{aA}$ & $3.82 \mathrm{aA}$ \\
BT.4.1 & $0.86 \mathrm{aA}$ & $3.17 \mathrm{aA}$ & $3.01 \mathrm{aA}$ & $1.44 \mathrm{aA}$ \\
BT.4.2 & $1.95 \mathrm{aA}$ & $0.80 \mathrm{aA}$ & $0.77 \mathrm{aA}$ & $9.08 \mathrm{bB}$ \\
BT.4.3 & $2.56 \mathrm{aA}$ & $2.69 \mathrm{aA}$ & $3.39 \mathrm{aA}$ & $0.84 \mathrm{Aa}$ \\
\hline
\end{tabular}

Keterangan: *Angka-angka pada arah horizontal yang diikuti huruf kecil yang sama dan angka-angka pada arah vertikal yang diikuti oleh huruf besar yang sama berbeda tidak nyata berdasarkan uji BNJ taraf 5\%.* Data yang disajikan adalah data asli, untuk sidik ragam dan BNJ adalah data transformasi $\sqrt{X+1}$

et al., 2003), dan pembelahan sel di stolon dihubungkan dengan penurunan kadar GA (Navarre dan Pavek, 2014). Retardan (alar) mampu merangsang pengumbian dengan jalan menghambat biosintesis giberelin yang berperan dalam pertumbuhan tanaman, karena inisiasi umbi membutuhkan giberelin yang rendah (Warnita, 2008).

\section{Hasil Tanaman Kentang}

Isolat rizobakteri yang diintroduksi pada benih dan tanaman kentang mampu meningkatkan hasil tanaman, yaitu: BT.4.1 (89.12 g) dan BT.4.3 (84.56 g) (Tabel 5). Hasil tanaman kentang yang terendah pada introduksi isolat BT.4.2 (51.57 g), sedangkan pada pemberian coumarin tidak berpengaruh nyata pada pembentukan umbi, rata-rata pemberian coumarin 0-150 $\mathrm{mg} \mathrm{L}^{-1}$ adalah 73-75 g.

Peningkatan bobot segar umbi tanaman kentang pada isolat rizobakteri BT.4.1 dan BT.4.3 dapat dilihat dari nilai luas daun yang terjadi pada dua isolat tersebut. Luas daun memberikan kontribusi positif pada pertumbuhan tanaman, memungkinkan tanaman mampu menggunakan semua cahaya yang mengenainya. Fotosintat hasil fotosintesis tersebut di translokasikan ke umbi. Menurut Tri et al. (2018) fotosintat yang dihasilkan digunakan untuk pembentukan umbi, karena proses umbi terkait erat dengan aktivitas pertumbuhan tanaman bagian atas, sehingga laju tumbuh umbi meningkat (Gambar 1), hal ini berbanding terbalik pada isolat rizobakteri BT.4.2. Meningkatnya luas daun pada pada isolat rizobakteri BT.4.2, digunakan untuk pertumbuhan bagian atas tanaman, dan berakibat pada tingginya peningkatan laju tumbuh relatif, sehingga bobot segar umbi yang dihasilkan lebih rendah.

Peningkatan bobot umbi segar juga memicu pembentukan umbi berdasarkan klasifikasi/kelompok umbi. Berdasarkan klasifikasi/kelompok umbi (Tabel 6, 7, dan 8), pada pemberian isolat rizobakteri dengan coumarin menunjukan bahwa umbi yang dihasilkan pada penelitian ini berukuran besar (Gambar 2). Umbi berukuran Small (S /kecil $<5$ g yang tertinggi pada kontrol (tanpa isolat rizobakteri dan tanpa coumarin), klasifikasi umbi Large (L)/ besar $>20 \mathrm{~g}$ yang terbaik dihasilkan oleh isolat rizobakteri BT.4.3, berbeda tindak nyata dengan BT.4.1 dan tanpa isolat rizobakteri, sedangkan klasifikasi umbi Medium (M) atau sedang 5-20 g tidak berbeda nyata.

Interaksi isolat rizobakteri dan konsentrasi coumarin menghasilkan bobot umbi yang lebih besar (Gambar 2), sehingga jumlah umbi berdasarkan klasifikasi umbi small (S), lebih sedikit jika dibandingkan dengan tanpa isolat rizobakteri dan tanpa coumarin. Hal ini merupakan dampak positif dari rhizobakteria dan coumarin, dimana rizobakteri bertindak dalam pembelahan sel di stolon dan konsentrasi coumarin bertindak sebagai pembentukan umbi. Niro et al. 
Tabel 5. Bobot segar umbi per tanaman (g) kentang umur 100 HST pada pemberian isolat Rizobakteri dan konsentrasi coumarin

\begin{tabular}{lccccc}
\hline \multirow{2}{*}{ Isolat bakteri } & \multicolumn{4}{c}{ Konsentrasi Coumarin $\left(\mathrm{mg} \mathrm{L}^{-1}\right)$} & Rata-rata \\
\cline { 2 - 5 } & 0 & 50 & 100 & 82.04 & $74.15 \mathrm{AB}$ \\
\hline Tanpa & 67.77 & 54.08 & 92.71 & 105.38 & $89.12 \mathrm{~B}$ \\
BT.4.1 & 79.17 & 89.77 & 82.13 & 42.16 & $51.57 \mathrm{~A}$ \\
BT.4.2 & 58.70 & 52.32 & 71.11 & 69.85 & $84.56 \mathrm{~B}$ \\
BT.4.3 & 97.44 & 98.99 & 74.97 & 74.86 & \\
\hline Rata-rata & 75.77 & 73.79 &
\end{tabular}

Keterangan: *Angka-angka pada arah vertikal yang diikuti huruf kecil yang sama berbeda tidak nyata berdasarkan uji BNJ taraf 5\%. ** Data yang disajikan adalah data asli, untuk sidik ragam dan BNJ adalah data transformasi $\sqrt{X+0.5}$
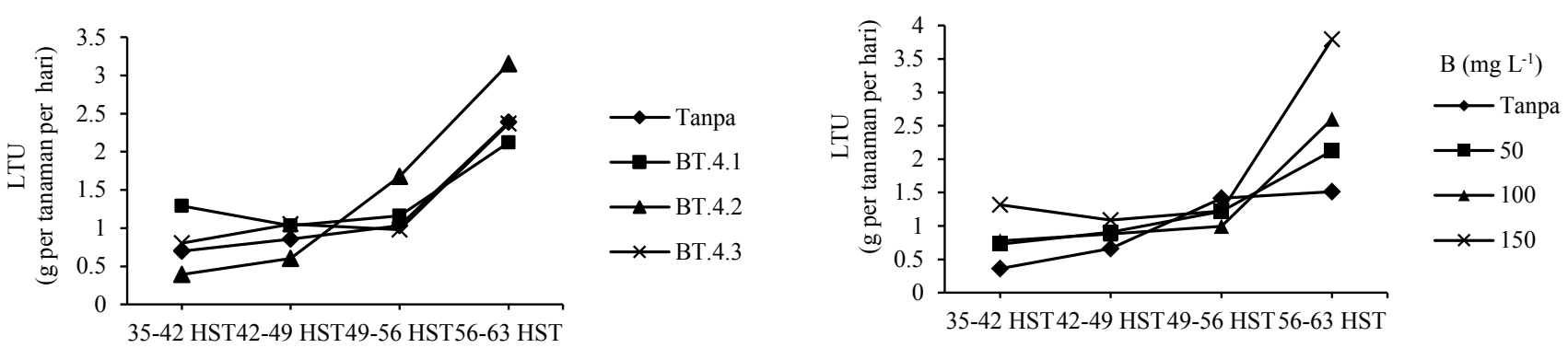

Gambar 1. Rata-rata laju tumbuh umbi tanaman kentang umur 35 HST-63 HST akibat pemberian (A) isolat Rizobakteri dan (B) konsentrasi coumarin $\left(\mathrm{mg} \mathrm{L}^{-1}\right)$

Tabel 6. Jumlah umbi berdasarkan kelas umbi small (S)/kecil $<5$ g umur 100 HST pada pemberian isolat rizobakteri dan konsentrasi coumarin $\left(\mathrm{mg} \mathrm{L}^{-1}\right)$

\begin{tabular}{lcccc}
\hline \multirow{2}{*}{ Isolat bakteri } & \multicolumn{4}{c}{ Jumlah umbi $(<5 \mathrm{~g})$} \\
\cline { 2 - 5 } & 0 & $50 \mathrm{mg} \mathrm{L}^{-1}$ & $100 \mathrm{mg} \mathrm{L}^{-1}$ & $150 \mathrm{mg} \mathrm{L}^{-1}$ \\
\hline Tanpa & $7.00 \mathrm{bB}$ & $2.00 \mathrm{aA}$ & $1.33 \mathrm{aA}$ & $1.00 \mathrm{aA}$ \\
BT.4.1 & $1.33 \mathrm{aA}$ & $1.67 \mathrm{aA}$ & $1.00 \mathrm{aA}$ & $1.00 \mathrm{aA}$ \\
BT.4.2 & $1.67 \mathrm{aA}$ & $0.67 \mathrm{aA}$ & $1.00 \mathrm{aA}$ & $1.67 \mathrm{aA}$ \\
BT.4.3 & $1.67 \mathrm{aA}$ & $3.33 \mathrm{aA}$ & $2.33 \mathrm{aA}$ & $4.33 \mathrm{aA}$ \\
\hline
\end{tabular}

Keterangan: *Angka-angka pada arah horizontal yang diikuti huruf kecil yang sama dan angka-angka pada arah vertikal yang diikuti oleh huruf besar yang sama berbeda tidak nyata berdasarkan uji BNJ taraf 5\%.* Data yang disajikan adalah data asli, untuk sidik ragam dan BNJ adalah data transformasi $\sqrt{X+1}$

Tabel 7. Jumlah umbi berdasarkan kelas umbi Medium (M)/sedang 5-20 g umur 100 HST pada pemberian isolat rizobakteri dan konsentrasi coumarin $\left(\mathrm{mg} \mathrm{L}^{-1}\right)$

\begin{tabular}{|c|c|c|c|c|c|}
\hline \multirow{2}{*}{ Isolat bakteri } & \multicolumn{4}{|c|}{ Jumlah umbi (5-20 g) } & \multirow{2}{*}{ Rata-rata } \\
\hline & 0 & $50 \mathrm{mg} \mathrm{L}^{-1}$ & $100 \mathrm{mg} \mathrm{L}^{-1}$ & $150 \mathrm{mg} \mathrm{L}^{-1}$ & \\
\hline Tanpa & 11.00 & 9.00 & 15.00 & 8.00 & 10.75 \\
\hline BT.4.1 & 10.00 & 12.67 & 6.67 & 13.00 & 10.58 \\
\hline BT.4.2 & 12.67 & 14.00 & 12.67 & 15.33 & 13.67 \\
\hline BT.4.3 & 20.33 & 10.33 & 10.00 & 14.00 & 13.67 \\
\hline Rata-rata & 13.50 & 11.50 & 11.08 & 12.58 & \\
\hline
\end{tabular}

Keterangan: *Angka-angka pada baris dan kolom yang sama berbeda tidak nyata menurut uji F pada taraf nyata $5 \%$. **Data yang disajikan adalah data asli, untuk sidik ragam dan BNJ adalah data transformasi $\sqrt{X+1}$ 
(2016) menjelaskan, bahwa eksudat akar mempengaruhi ketersediaan coumarin dan efektivitas mikroorganisme, dimana pengaruh rhizobakteria tersebut berkorelasi positif dan negatif, sehingga memiliki respon yang berbeda terhadap hasil tanaman, hal ini juga dipengaruhi oleh ketersediaan unsur hara pada media tanam yang digunakan saat penanaman (Tabel 9).

Tabel 8. Jumlah umbi berdasarkan kelas umbi Large (L)/besar > 20 g umur 100 HST pada pemberian isolat Rizobakteri dan konsentrasi coumarin $\left(\mathrm{mg} \mathrm{L}^{-1}\right)$

\begin{tabular}{|c|c|c|c|c|c|}
\hline \multirow{2}{*}{ Isolat bakteri } & \multicolumn{4}{|c|}{ Jumlah umbi $(>20 \mathrm{~g})$} & \multirow{2}{*}{ Rata-rata } \\
\hline & 0 & $50 \mathrm{mg} \mathrm{L}^{-1}$ & $100 \mathrm{mg} \mathrm{L}^{-1}$ & $150 \mathrm{mg} \mathrm{L}^{-1}$ & \\
\hline Tanpa & 2.33 & 3.00 & 5.00 & 3.67 & $3.50 \mathrm{AB}$ \\
\hline BT.4.1 & 4.00 & 4.33 & 5.67 & 6.67 & 5.17AB \\
\hline BT.4.2 & 3.00 & 3.33 & 2.67 & 2.33 & $2.83 \mathrm{~A}$ \\
\hline BT.4.3 & 5.33 & 6.67 & 7.33 & 3.33 & $5.67 \mathrm{~B}$ \\
\hline Rata-rata & 3.67 & 4.33 & 5.17 & 4.00 & \\
\hline
\end{tabular}

Keterangan: *Angka-angka pada arah vertikal yang diikuti huruf kecil yang sama berbeda tidak nyata berdasarkan uji BNJ taraf 5\%. ** Data yang disajikan adalah data asli, untuk sidik ragam dan BNJ adalah data transformasi $\sqrt{X+1}$

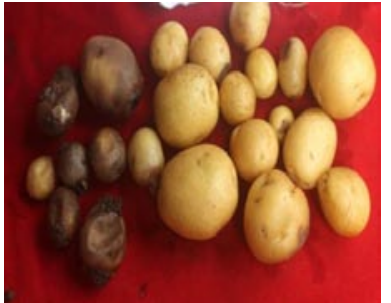

Tanpa Isolat bakteri dan 0 Coumarin $\left(\mathrm{mg} \mathrm{L}^{-1}\right)$

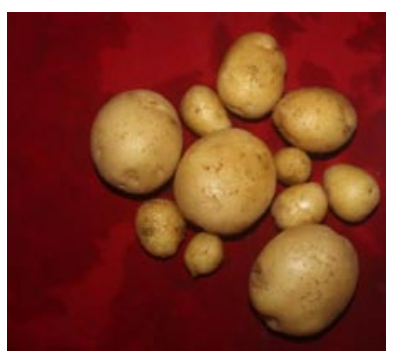

BT.4.1 dan 0 Coumarin $\left(\mathrm{mg} \mathrm{L}^{-1}\right)$

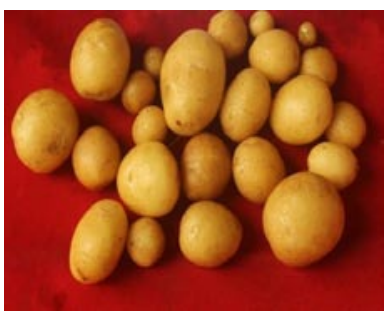

BT.4.2 dan 0 Coumarin $\left(\mathrm{mg} \mathrm{L}^{-1}\right)$

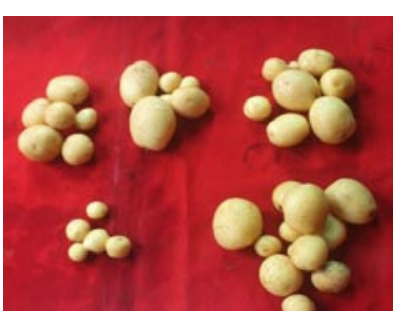

BT.4.3 dan 0 Coumarin $\left(\mathrm{mg} \mathrm{L}^{-1}\right)$

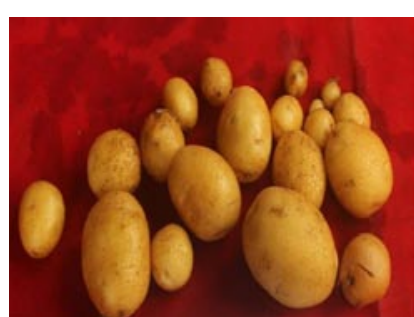

Tanpa Isolat bakteri dan 50 Coumarin $\left(\mathrm{mg} \mathrm{L}^{-1}\right)$

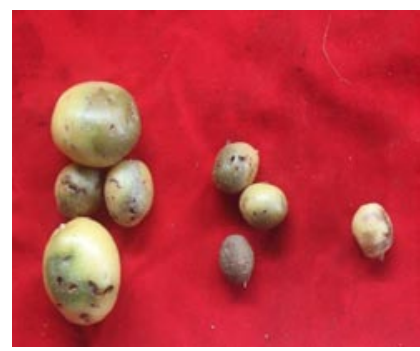

BT.4.1 dan 50 Coumarin (mg L-1)

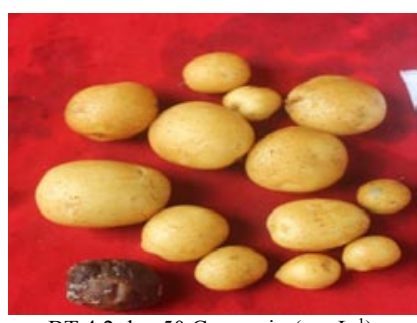

BT.4.2 dan 50 Coumarin $\left(\mathrm{mg} \mathrm{L}^{-1}\right)$

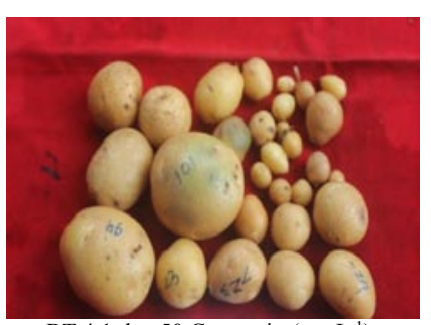

BT.4.1 dan 50 Coumarin $\left(\mathrm{mg} \mathrm{L}^{-1}\right)$

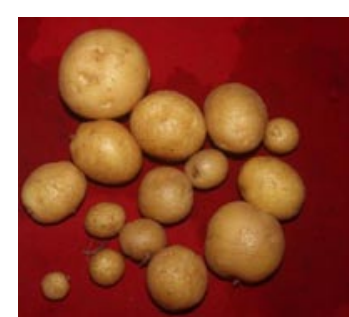

Tanpa Isolat bakteri dan 100 Coumarin $\left(\mathrm{mg} \mathrm{L}^{-1}\right)$

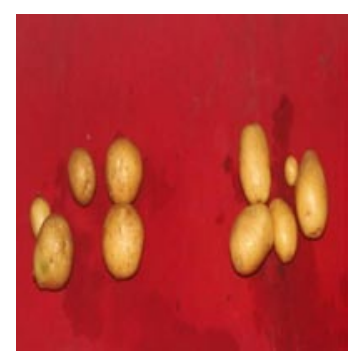

BT.4.1 dan 100 Coumarin $\left(\mathrm{mg} \mathrm{L}^{-1}\right)$

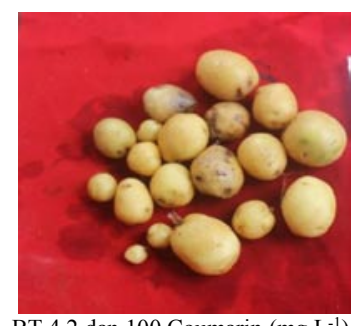

BT.4.2 dan 100 Coumarin $\left(\mathrm{mg} \mathrm{L}^{-1}\right)$

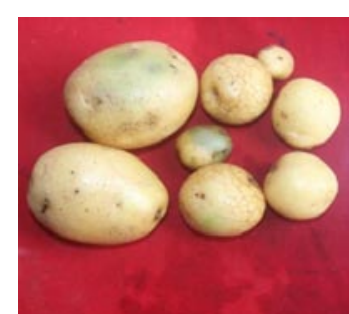

BT.4.1 dan 100 Coumarin (mg L $\left.{ }^{-1}\right)$

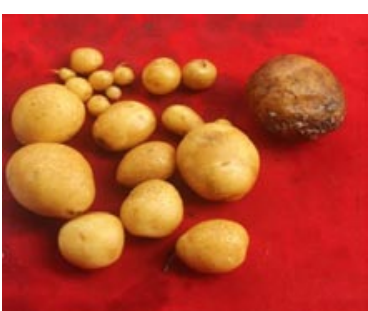

Tanpa Isolat bakteri dan 150 Coumarin $\left(\mathrm{mg} \mathrm{L}^{-1}\right)$

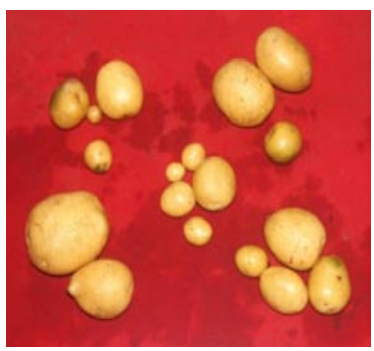

BT.4.1 dan 150 Coumarin $\left(\mathrm{mg} \mathrm{L}^{-1}\right)$

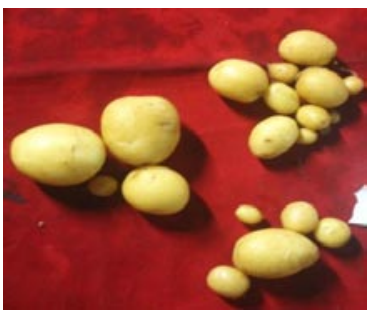

BT.4.2 dan 150 Coumarin $\left(\mathrm{mg} \mathrm{L}^{-1}\right)$

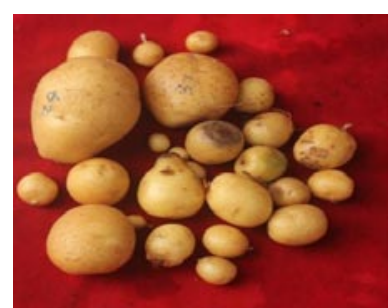

BT.4.1 dan 150 Coumarin $\left(\mathrm{mg} \mathrm{L}^{-1}\right)$

Gambar 2. Umbi kentang Granola setelah panen pada umur 100 HST 
Tabel 9. Hasil analisis awal kimia tanah di kebun percobaan Pusat Alih Teknologi dan Pengembangan Kawasan Pertanian Universitas Andalas (PATPKP UNAND), Alahan Panjang, Kabupaten Solok, Sumatera Barat

\begin{tabular}{lccc}
\hline Jenis & Satuan & Nilai & Kriteria \\
\hline $\mathrm{pH} \mathrm{H} \mathrm{H}_{2}(1: 2)$ & & 4,186 & Sangat masam \\
N-Total & $\%$ & 0,352 & Sedang \\
C- Organik & $\%$ & 7,656 & Tinggi \\
B- Organik & $\%$ & 13,199 & Tinggi \\
C/N & $\%$ & 21,751 & Rendah \\
P-tersedia & ppm & 49,993 & - \\
K-dd & me $100 \mathrm{~g} \mathrm{~g}^{-1}$ & 0,171 & Netral \\
Al-dd & me $100 \mathrm{~g} \mathrm{~g}^{-1}$ & ttd & 36,322 \\
KTK & me $100 \mathrm{~g} \mathrm{~g}^{-1}$ & & \\
\hline
\end{tabular}

Sumber: Laboratorium Analisis Tanah Fakultas Pertanian Universitas Andalas Padang

\section{KESIMPULAN}

Interaksi rizobakteri dan coumarin mampu meningkatkan luas daun pada tanaman kentang pada pemberian rizobakteri BT.4.1 dengan coumarin $100 \mathrm{mg} \mathrm{L}^{-1}$ dan BT.4.2 dengan coumarin $150 \mathrm{mg} \mathrm{L}^{-1}$, laju pertumbuhan relatif meningkat pada tanaman kentang pada pemberian rizobakteri BT.4.2. dengan coumarin $150 \mathrm{mg} \mathrm{L}^{-1}$, Laju tumbuh umbi meningkat pada tanaman kentang pada pemberian rizobakteri BT.4.2 dengan coumarin $150 \mathrm{mg} \mathrm{L}^{-1}$, sedangan untuk hasil tanaman kentang lebih dipengaruhi pada pemberian rizobakteri BT.4.1 dan BT.4.3.

\section{UCAPAN TERIMA KASIH}

Tim Peneliti berterimakasih kepada DIPA UNAND yang telah membantu mendanai pelaksanaan penelitian ini sesuai surat perjanjian pelaksanaan Penegasan Hibah Klater Riset Guru Besar Tahun Anggaran 2016 No. 524/XIV/A/ UNAND.

\section{DAFTAR PUSTAKA}

Ahemad, M., M. Kibret. 2014. Mechanisms and applications of plant growth promoting rhizobacteria: current perspective. King Saud Uni-Sci. 26:1-20.

Pusat Statistik Indonesia. 2017. Luas panen, Produksi dan produktivitas Kentang. Statistik Indonesia. Sumber: Badan Pusat Statistik dan Direktorat Jenderal Hortikultura, Jakarta, ID.

Antonio, L., F. Araniti, F. Sunseri, M.R Abenavoli. 2014. Coumarin interacts with auxin polar transport to modify root system architecture in Arabidopsis thaliana. Plant Growth Regul. 74:23-31

Chattha, F.A., M. Nisa, M.A. Munawer, S. Kousar. 2016. Coumarin-based heteroaromatics as plant growth regulators. Publ. Intech. 7:92-105.
Cheynier, V., G. Comte, K.M. Davies. 2013. Plant phenolics: Recent advances on their biosynthesis, genetics, and ecophysiology. Plant Physiol. Biochem. 72:1-20.

Derek S.L., P.J.P.L. Teixeirab. 2018. Root-exuded coumarin shapes the root microbiome. Proceedings of the National Academy of Sciences of the United States of America 115:5629-5631.

Direktorat Perbenihan Hortikultura. 2014. Teknis Perbanyakan dan Sertifikasi Benih Kentang. Jakarta. Kementerian Pertanian.

Elango. R., R. Parthasarathi., S. Megala. 2013. Elango. R., R. Parthasarathi, S. Megala. 2013. Field level studies on the association of plant growth promoting rhizobacteria (PGPR) in Gloriosa superba L. rhizosphere. Indian Streams Res. 3:1-6.

[FAO] Food and Agriculture Organization of the United Nations. 2014. Statistical Pocketbook World food and Agriculture. Rome, IT.

[FAO] Food and Agriculture Organization of the United Nations. 2015. Statistical Pocketbook World food and Agriculture. Rome, IT.

Fifi, P., S.I. Saputra, J. Merini. 2018. Uji beberapa konsentrasi bakteri Bacillus sp. endofit untuk meningkatkan pertumbuhan bibit kakao (Theobroma cacao L.). J. Agron. Indonesia 46:322-327.

Gardner, F.P., R.B. Pearce, R.L. Mitchel. 1991. Fisiologi tanaman budidaya. Terjemahan. H. Susilo, Subiyanto (Ed.). UI Press. Jakarta, ID.

Glick, B.R. 2012. Plant Growth-Promoting Bacteria: Mechanisms and Applications. Hindawi Publishing Corporation Scientifica. 
Jnawali, A.D., R.B. Ojha, S. Marahatta. 2015. Role of azotobacter in soil fertility and sustainability-A review. Adv. Plants Agric. Res. 2:250-253.

Kai, K., B. Shimizu, M. Mizutani, K. Watanabe, K. Sakata. 2006. Accumulation of coumarins in Arabidopsis thaliana. Phytochemistry. 67:379-386.

Kefeli, V., M. Kalevitch. 2003. Natural Growth Inhibitors and Phytohormones in Plants and Enviroment. Springer. USA.

Li, X., M.Y. Gruber, D.D. Hegedus, D.J. Lydiate, M.J. Gao. 2011. Effects of a coumarin derivative, 4methylumbelliferone, on seed germination and seedling establishment in Arabidopsis. J. Chem. Ecol. 37:880-90.

Lupini, A., A. Sorgonà, Anthony, J. Miller, M.R. Abenavoli. 2010. Short-term effects of coumarin along the maize primary root axis. Plant Signaling Behav. 5:13951400.

Navarre, R., M. Pavek. 2014. The Potato Botany. CAB International. US.

Niro, E., R. Marzaioli, S. Crescenzo, B. Abrosca, S. Castaldi, A. Esposito, A. Fiorentino, F. Rutigliano. 2016. Effects of the allelochemical coumarin on plants and soil microbial community. Soil Biol. Biochem. 95:30-39.

Piromyou, P, B. Buranabanya, P. Tantasawat, P. Tittabutr, N. Boonkerd, N. Teaumroong. 2011. Effect of plant growth promoting rhizobacteria (PGPR) inoculation on microbial community structure in rhizosphere of forage corn cultivated in Thailand. Europ. Soil Biol. 47:44-54.

[PUSTADIN] Pusat Data dan Sistem Informasi Pertanian. 2015. Statistik Konsumsi Pangan. Kementerian Pertanian. Jakarta.

Pusat Data dan Sistem Informasi Pertanian. 2015. Statistik Konsumsi Pangan. Kementerian Pertanian. Jakarta.
Rodrigo, M., P. Garbeva, J.M. Raaijmakers. 2013. The rhizosphere microbiome: significance of plant beneficial, plant pathogenic, and human pathogenic microorganisms. FEMS Microbiol. Rev. 37:634663.

Souza, R., A. Beneduzi, A. Ambrosini, P.B. Costa, J. Meyer, L.K. Vargas, R. Schoenfeld, L.M.P Passaglia. 2013. The effect of plant growth-promoting rhizobacteria on the growth of rice (Oryza sativa L.) cropped in southern Brazilian fields. Plant Soil 366:585-603.

Souza, R., A. Ambrosini, L. Passaglia. 2015. Plant growthpromoting bacteria as inoculants in agricultural soils. Genet. Molec. Biol. 38:401-419.

Syarif, Z. 2004. Pertumbuhan dan hasil tanaman kentang dengan dan tanpa diikat pada turus dalam sistem tumpansari kentang/jagung di dua lokasi dataran medium berbeda elevasi. Disertasi. Sekolah Pascasarjana. Universitas Padjajaran. Bandung.

Tri, I.O., Z. Syarif, Y. Yanti, Warnita. The growth and yield of potato (Solanum tuberosum L.) with application of indigenous rhizobacteria and coumarin. Int. J. Agric. Innov. Res. 7:2319-1473.

Warnita. 2008. Modifikasi media pengumbian kentang dengan beberapa zat penghambat tumbuh. Jerami $1: 50-52$.

Yanti, Y., T. Habazar, Z. Resti, D. Suhalita. 2013. Penapisan isolat rizobakteri dari perakaran tanaman kedelai yang sehat untuk pengendalian penyakit pustul bakteri (Xanthomonas axonopodis pv. glycines). J. HPT Tropika 13:24-34.

Zakry, F.A.A., Z.H. Shamsuddin, K.A. Rahim, Z. Zakaria, A.A. Rahim. 2012. Inoculation of Bacillus sphaericus UPMB-10 to young oil palm and measurement of its uptake of fixed nitrogen using the $15 \mathrm{~N}$ isotope dilution technique. Microbes Environ. 27:257-262. 